\title{
CONCENTRATION OF NON-AGRICULTURAL ECONOMIC ACTIVITY IN POLAND
}

\author{
Wieslawa Lizinska ${ }^{1}$, prof. UWM dr hab.; Roman Kisiel ${ }^{2}$, prof. zw. dr hab.
} 1,2 University of Warmia and Mazury in Olsztyn

\begin{abstract}
The aim of the article is to analyse and assess the concentration of non-agricultural activities in Poland as an element of the alternative use of agricultural real estate. A detailed analysis will cover the spatial aspect of the concentration of the conducted activity. In order to determine the concentration, the location quotient (LQ) was used. The article used the current data of the Central Statistical Office regarding the characteristics of agricultural holdings in Poland in 2016. While the income from non-farm businesses conducted by farmers reached $15.2 \%$ of farms' total income on average for whole Poland, certain diversity can be seen among provinces. It is worth emphasising that for as many as $49.2 \%$ of agricultural holdings conducting non-farm businesses, the revenues derived from such economic activity make up more than $50 \%$ of the total income. In particular regions, however, the share of such farms was varied, yet remaining on a relatively high level, i.e. between nearly $40 \%$ to $58.2 \%$, in all the country. The significantly greater diversity of the economically largest farms was not accompanied by greater differences in the concentration of farms gaining income from non-agricultural businesses.
\end{abstract}

Key words: non-agricultural activity, farm, spatial concentration, location coefficient, Poland. JEL code: O13, Q12, Q15.

\section{Introduction}

The research accomplished in the late 1990s implicates that the non-agricultural economic activity in rural areas in Poland had been developing very unevenly. The economic entities of a nonagricultural type were most densely concentrated in the western provinces. The weakest saturation with such businesses appeared along the eastern border of the country (Banski, 2004). The analysis of non-farm business activities at private farms made by Kolodziejczyk (2004) also demonstrated quite a large diversity in the scale of such enterprises. This was mostly due to the differences in personality traits among farm owners and in the technological supplies of farms. However, the expected vector of the dependence between the growth of non-agricultural functions and the level of infrastructure and economic potential of agricultural holdings was not confirmed by Czapiewski (2004).

The outcome of the current investigations also testifies to large spatial differentiation among farms which pursue non-agricultural economic activity. As noted by Czudec and Zajac (2017), the biggest discrepancies appear among organic farms, while farms with an additional non-agricultural business, including agritourism farms, are less diverse in this regard, and farms which sell their products directly to consumers are the least varied.

The research conducted worldwide can shed light on discrepancies between regions in terms of non-farm economic activities carried out by farmers. For instance, Von Braun and Pandya-Lorch (1991) observe that households with strong economic standing are more likely to diversify their sources of income, as this may allow them to enhance the accumulation of capital.

Reardon and co-authors (2000) underline that poorer households have a lesser chance to overcome entry barriers and therefore limit themselves to undertaking such activities that do not generate high profits. The widely implemented programmes aiming to create employment outside agriculture and start microbusinesses do not necessarily solve the problem of unequal incomes in

\footnotetext{
${ }^{1}$ Faculty of Economic Sciences, University of Warmia and Mazury in Olsztyn, ul. Oczapowskiego 4/202, 10-718 Olsztyn, Poland, email:wieslawa.lizinska@uwm.edu.pl

${ }^{2}$ Faculty of Economic Sciences, University of Warmia and Mazury in Olsztyn, ul. Oczapowskiego 4/200, 10-718 Olsztyn, Poland, email:kisiel@uwm.edu.pl
} 
rural areas, nor do they automatically provide the poorest households with benefits. Conversely, they can cause societal tensions. In current policy, it is therefore essential to draw attention to the access of less affluent households to the resources that will enable them to overcome entry barriers and break into the market outside farming.

The mechanism behind the diversification of revenue sources dependent on the availability of assets is repeatable and generates a feedback effect. Households with a better economic status accumulate assets, which are the basis for further profitable diversification. On the other hand, poorer households operate in the same sectors, with a low level of capital return, which adds to the overall increase in inequalities (Barrett et al., 2001).

The development of non-agricultural activity gives rise to the emergence of alternative sources of income, beside farming, which support all households. As emphasised by Banski (2004), this happens even in areas where agriculture is characterised by a high level of development and provides farmers with satisfactory revenues. However, there are areas that require particularly rapid changes in the functional structure because agriculture alone secures ever diminishing earnings and provides farmers and their families with the subsistence minimum.

Weltin and co-authors (2017) highlight the fact that various forms of income diversification are a manifestation of important strategies implemented by farmers. The aim is to respond to the changing economic environment. A decision to diversify business activities on or outside a farm will depend, to a large extent, on the type of farming and other characteristics of a particular farm. As implicated by the up-to-date studies, young farmers on organic farms are most likely to target at diversification. A diversification strategy is the least frequently pursued on intensive, large-scale farms, and on farms with varied agricultural production or by households which obtain only some of the income from farming. The research results also showed that while facing the prospect of hypothetically terminated subsidies from the Common Agricultural Policy (CAP) more and more farmers might employ the strategy of diversification of revenues, mostly outside agriculture, in order to survive.

As suggested by Birthal and co-authors (2014), there is a wide range of push and pull factors concerning the non-agricultural activities undertaken by farmers. A small acreage of a farm (Kisiel, Jarzebowicz, 2017, Krakowiak-Bal, 2009), low income and surplus labour force available on a farm are the conditions which push the farm outside of the agricultural sector (Zmija, 2018). The level of education and the access to credit facilitate the shift to a non-farm sector of economy.

In some countries, non-farm economy functions as an alternative to agriculture rather than a supplementary business activity (Canagarajah et al., 2001). A question arises which of the following factors plays a more significant role in developing non-farm businesses: inadequate incomes and a need to secure alternative sources of revenue, or a wish to employ the farm's potential in order to develop a non-farm business and to focus on the latter? A non-agricultural activity often requires specific investment means, which underdeveloped farms usually lack. On the other hand, such farms feel a stronger urge to search for alternative sources of income. A combination of push and pull factors can determine the spatial concentration of non-farm businesses in rural areas.

The aim of the research has been to analyse and assess the concentration of non-agricultural activities in Poland as an element of the alternative acquisition of income sources. A detailed analysis covered the spatial aspect of the conducted activities. The location quotient (LQ) served to determine the concentration. Values of this quotient provide data serving to assess the level of concentration of the analysed factor. The threshold value of LQ is assumed to be 1.00 . What this means is that if an LQ equals 1.00 , the concentration of non-agricultural activities run by farmers in a given area is 
the same as the average concentration of non-farm economy in the whole country. In our study, the LQ values were derived from the equation:

$$
L Q_{i}=\frac{N P_{W O J(i)} / N G_{W O J(i)}}{N P_{P L} / N G_{P L}}(1)
$$

where:

LQi - location quotient of non-agricultural activities in the ith province of Poland, where

$i \in\{1, \ldots, 16\}$, relative to the number of farms in the ith province,

NPWOJ(i) - number of farms conducting non-agricultural activities in the ith province,

NGWOJ(i) - number of farms in the ith province,

NPPL(i) - number of farms conducting non-agricultural activities in Poland,

NGPL(i) - number of farms in Poland.

To assess the degree of concentration, the following intervals for the LQ values were adopted:

- an LQ value >1 means higher concentration of the analysed characteristic than on average in Poland;

- an LQ value $<1$ means a potential deficit in the analysed characteristic;

- an LQ value $=1( \pm 0.15)$ means that the distribution of the analysed variable runs a similar course as the distribution of this variable in the reference area.

A preliminary analysis and evaluation of the non-agricultural activity on farms as found in the Polish provinces were made, and the results were used to calculate the concentration coefficients. The following were included:

- regional differentiation of farms which earn income from non-agricultural activity,

- share of farms which earn income from non- agricultural activity in the total number of family farms in particular provinces,

- share of households where over $50 \%$ of total revenue originated from non-agricultural activity in the total number of farmers' households that earn income from non-farm business,

- share of the economically smallest farms (>100 thousand euro).

The subsequent stage of the study consisted of calculating the location quotient for the economically largest farms (>100 thousand euro), farms earning income from non-agricultural activity, and farms conducting non-agricultural activity where over $50 \%$ of total income originated from non-agricultural activity.

The authors based their research on current and available data for 2016 of the Polish Central Statistical Office (CSO), regarding the statistics of farms in Poland.

\section{Research results and discussion}

The Polish provinces are distinctly varied in terms of the share of farms obtaining some income from non-agriculture activity in the total number of this group of farms in Poland. In Lubuskie Province, for example, this percentage equalled $1.7 \%$, while in the Province of Masovia it was as high as $15.1 \%$ (fig. 1). In two provinces the percentage of such farms was close in value to the share of farms in the same region in the total number of farms in Poland. In nine other provinces, the share of farms earning income from non-agricultural activity was higher than the share of farms in a given province in the total number of farms in Poland, although the difference did not exceed 1 per cent point. In five provinces, the share of farms earning some revenue from non-farm economic activity was lower that the share of farms in each of these provinces in the total number of Polish farms. Attention can be drawn to the situation in the Province of Lublin, where the greatest 
discrepancy between the values of these two statistical measures was seen. It can therefore be said that one of the factors which largely determine the share of agricultural households in a given region in the total number of such households earning the income from non-agricultural activities is the total number of farms in the said region.

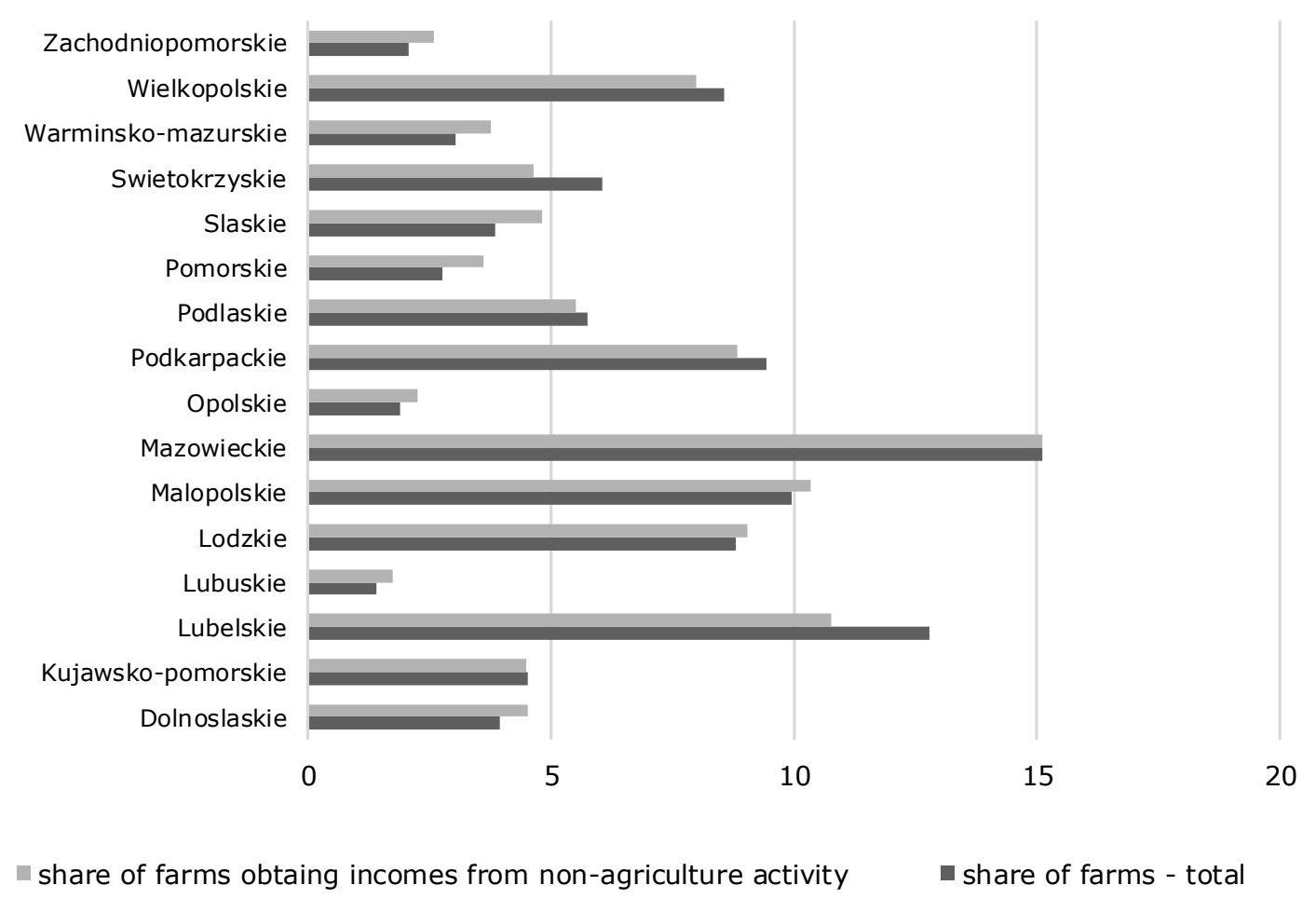

Source: author's calculation based on CSO data

Fig. 1. Regional diversification of total number of farms and farms obtaining incomes from non-agriculture activity ( \%)

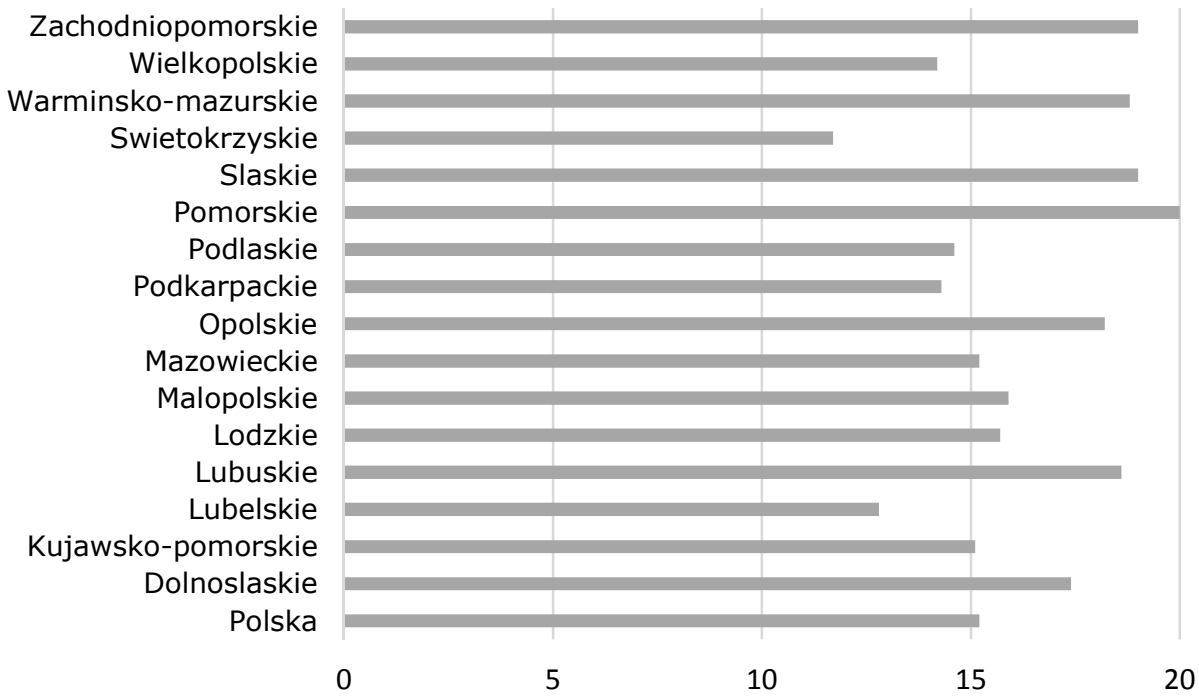

Source: author's calculation based on CSO data

Fig. 2. Share of farms obtaining incomes from non-agriculture activity in total number of farms in each region (\%)

It was demonstrated that the percentage of farms earning income from non-agricultural activities in the Polish provinces deviated, to a different extent among the regions, from the share of farms in a province in the total number of farms in Poland, which led to the next step in the research, namely 
an analysis of the level of concentration of non-farm economy in each province. Thus, it was calculated what percentage of farms out of all farms in each province earned income from nonagricultural activity. As demonstrated by the data (fig. 2), revenue from non-farm economy is derived by an average of $15.2 \%$ of farms in whole Poland. A percentage higher than that was calculated for 9 provinces, of which the Province of Pomerania scored the highest $(20.0 \%)$. In 6 provinces, the percentage of such farms was lower than the Polish average, with the lowest figure $(11.7 \%)$ calculated for the Province of Swietokrzyskie.

The role of farming in the diversification of income sources can be demonstrated not only through the share of farms earning revenues from non-farm businesses but also by the share of such earnings in the total income of a farm. As shown by the data in figure 3 , in the total number of farms obtaining some income from non-farm economic activities in Poland (214 447 farms), nearly half (49.2\%) made up over $50 \%$ of the total earnings from non-farm economy. This measure varied in value among the Polish provinces, but always remained relatively high. In the province with the lowest share of farms whose income from non-farm business activities reached over $50 \%$ of the total income, the contribution of this income to the total earnings was $40 \%$. In the Province of Podkarpacie, it was as high as $58.2 \%$.

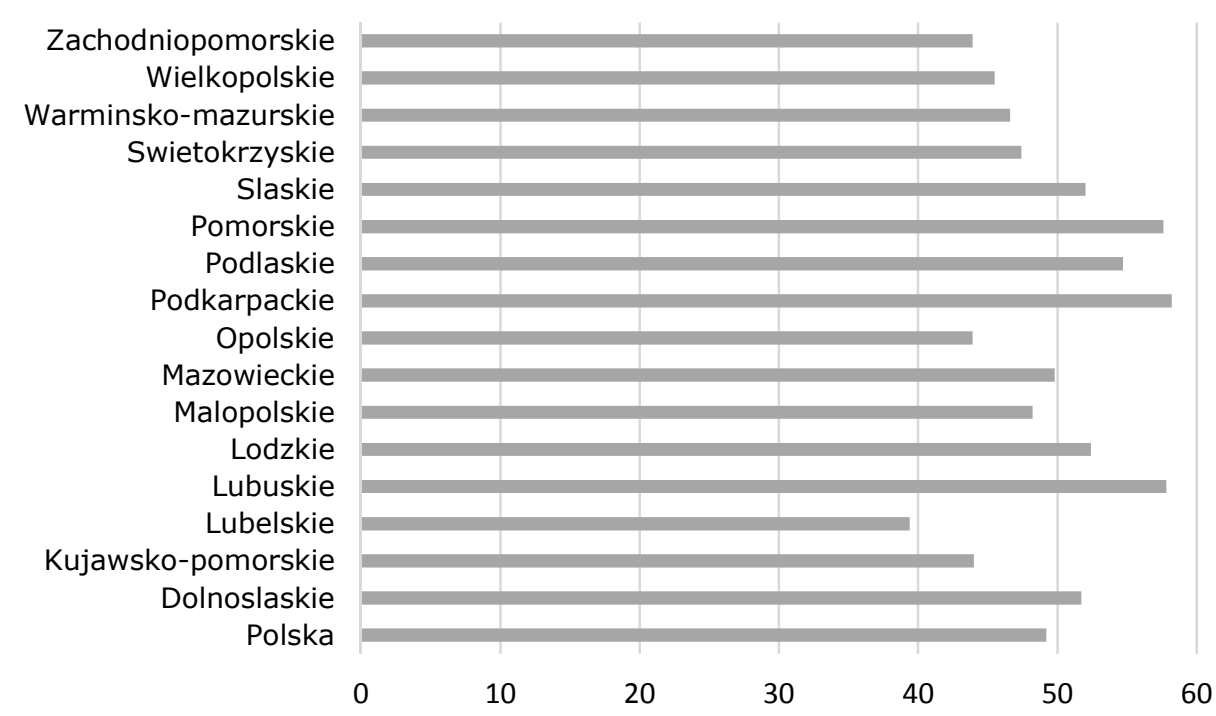

Source: author's calculation based on CSO data

Fig. 3. Share of households whose more that $\mathbf{5 0} \%$ of incomes are incomes from nonagricultural activity in total number of farms obtaining incomes from non-agricultural activity - \%

In an attempt to answer the resolve whether a decision to undertake a non-farm business activity arises from a strategy assuming an alternative use of an agricultural real estate property or is a way to achieve diversification of income sources, the authors determined the concentration of farms which were economically the largest. It was agreed that these are the farms with the standard production output of more than 100,000 Euro.

The data (fig. 4) prove that the highest share of economically the largest farms can be found in the provinces which at the onset of the social and economic transformation in Poland had the highest share of state-owned farmland. They were the following provinces: warminsko-mazurskie $(5.6 \%)$, zachodniopomorskie $(5.4 \%)$, as well as wielkopolskie $(4.9 \%)$ and lubuskie $(4.9 \%)$. On the other hand, the percentage of state-owned farmland in the provinces podkarpackie and malopolskie did not exceed $0.4 \%$ at that time. 
It can therefore be noticed that the intraregional differentiation among the farms earning revenues from non-farm economy and among the economically largest farms is similar when measured on the scale of the whole country. This similarity is confirmed by the differences being equal No more than a few per cent points between the province with the largest and the one with the smallest share of the two groups of farms mentioned above.

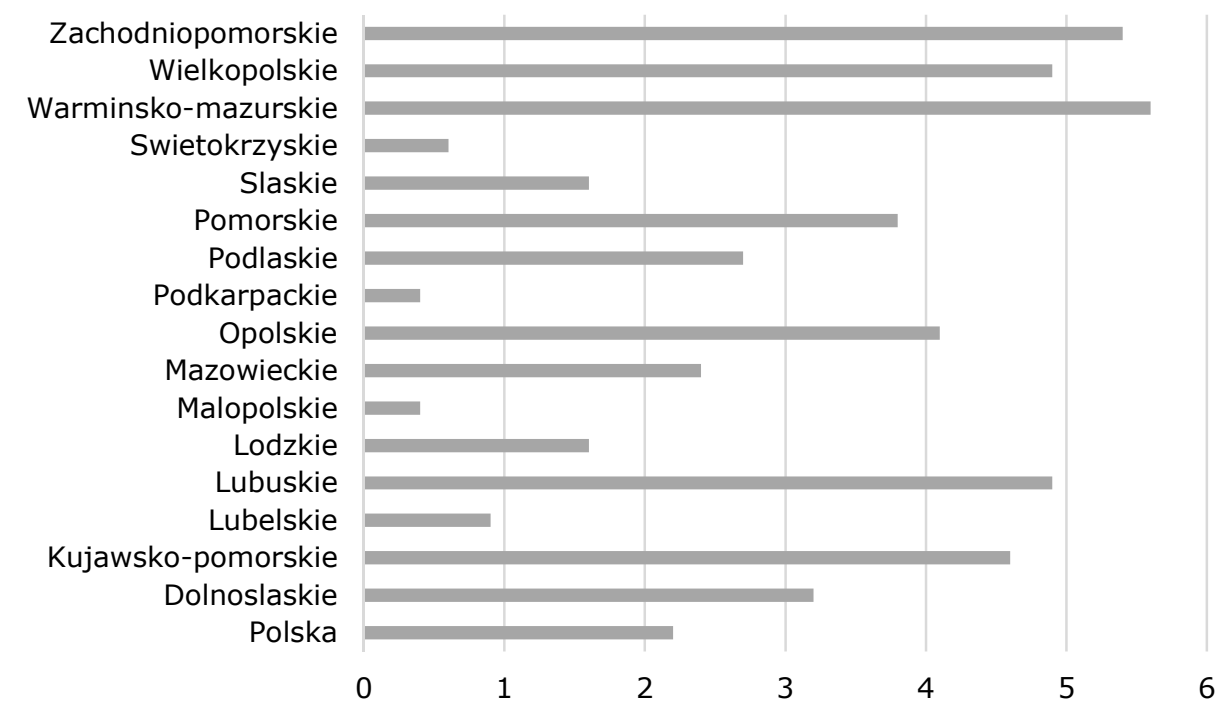

Source: author's calculation based on CSO data

Fig. 4. Share of farms with the highest level of economic size (>100.000 EUR) - \%

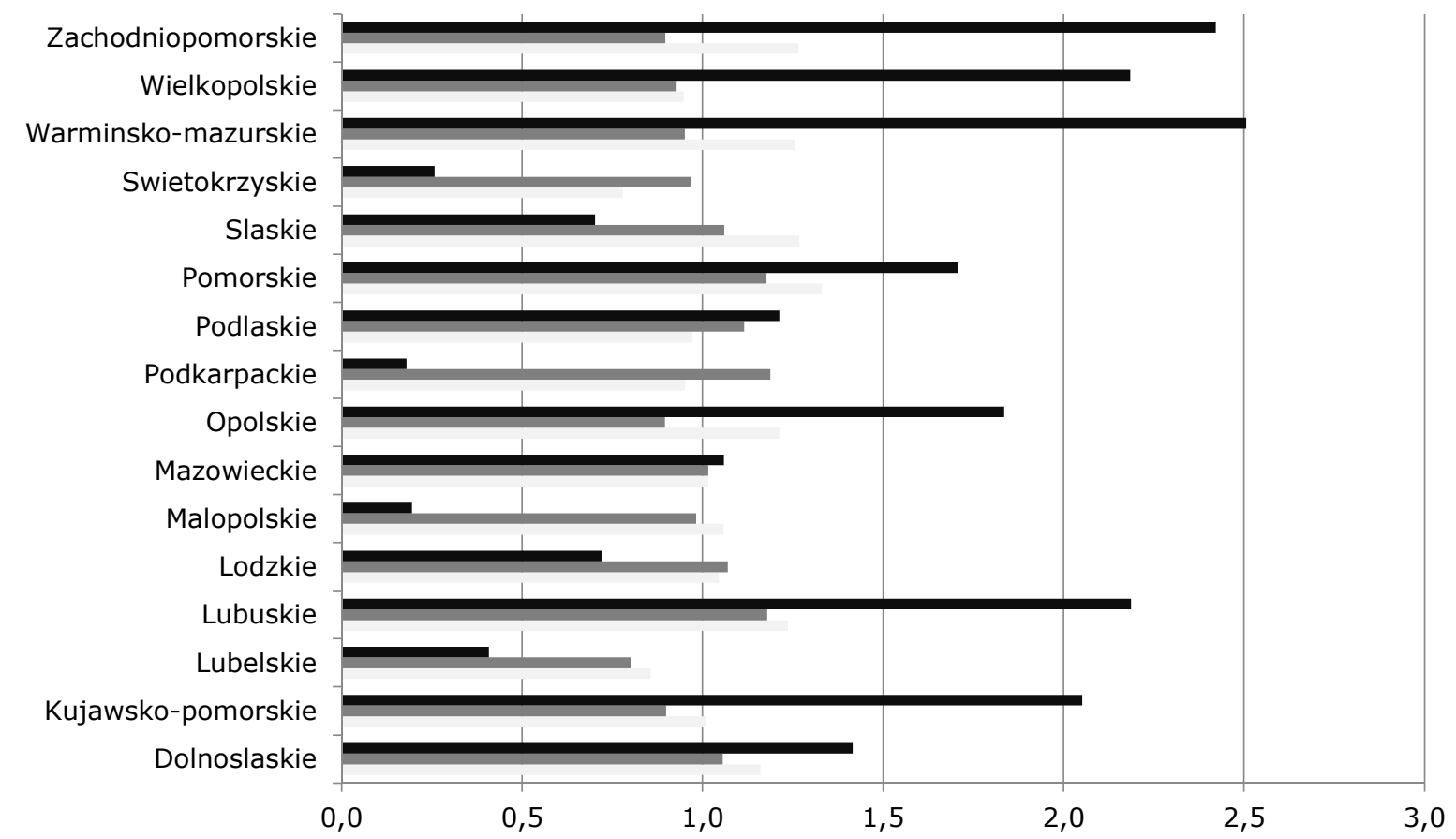

- LQ of farms with the higher level of economic size (> 100 tys. EUR)

- LQ of farms who generate more than $50 \%$ incomes from non-agriculture activity

LQ of farms obtaing incomes from non-agriculture activity

Source: author's calculation based on CSO data

Fig. 5. Regional diversification of $L Q$ in chosen farms group

The analyses of the concentration of non-farm economic activities and farms obtaining income from non-farm businesses (where such income corresponded to over $50 \%$ of the total income), as 
well as the concentration of farms which are economically the largest allowed us to calculate the synthetic index of the concentration of farms within the analysed categories.

The data presented in this paper prove that there are differences among the Polish provinces in the concentration of all the analysed categories of farms. Considering the farms which earn income from non-farm businesses, the concentration index was higher than the reference one in 7 provinces, where it ranged from 1.16 to 1.33 . It was only in one province (swietokrzyskie) that the value of the concentration index (0.78) was lower than calculated for the reference area. In 8 provinces, on the other hand, the concentration of the farms which acquired income from non-farm economy was similar to that calculated from the whole country.

With regard to farms which conduct non-farm businesses where over $50 \%$ of the total income was composed of the revenues gained from non-farm economy, differences in their concentration between individual provinces were smaller. Of the 16 Polish provinces, the value of the concentration index was higher than in the references area in just 3 provinces (pomorskie, podkarpackie, lubuskie), being lower in one province (lubelskie). Thus, in as many as 12 provinces, the concentration of farms conducting non-farm economic activity and earning a high level of revenues (compared to their total income) was similar to the average value computed for Poland.

When referring the results of the analysis presented above to the variation in the index of concentration of economically the largest farms, also discussed in this article, it can be observed that the much higher diversity among the latter agricultural holdings does not coincide with greater differences in the concentration of farms earning income from non-farm economy. Nonetheless, 5 out of the 8 provinces with the concentration of economically the largest farms above the average were noted to attain the value of the concentration index of farms earning income from non-farm businesses above the reference value.

\section{Conclusions}

1) The analyses performed in this study have demonstrated that the share of farms in a given province in the total number of farms earning income from non-farm economic activities is in general convergent with the share of farms in the given province in the total number of farms in Poland. Except one province, differences in these percentages did not exceed 1 per cent point.

2) While the income from non-farm businesses conducted by farmers reached $15.2 \%$ of farms' total income on average for whole Poland, certain diversity can be seen among provinces. Higher values were noted in 9 provinces, of which the highest share $(20.0 \%)$ was recorded in the Province of Pomerania. In 6 provinces, this percentage was less than the country's average, being the lowest $(11.7 \%)$ in the Province of Swietokrzyskie.

3 ) It is worth emphasising that for as many as $49.2 \%$ of agricultural holdings conducting non-farm businesses, the revenues derived from such economic activity make up more than $50 \%$ of the total income. In particular regions, however, the share of such farms was varied, yet remaining on a relatively high level, i.e. between nearly $40 \%$ to $58.2 \%$, in all the country.

4) Differences in the concentration of all analysed categories of farms were noticed among the provinces in Poland. At the same time, for the group of farms conducting non-farm business activities where the income from such activities accounted for over $50 \%$ of total revenue, the variation of the concentration index was lower than for all farms generating revenues from nonagricultural activities. 
5) It was also found that the significantly greater diversity of the economically largest farms was not accompanied by greater differences in the concentration of farms gaining income from nonagricultural businesses.

\section{Bibliography}

1. Banski, J. (2004). Mozliwosci rozwoju alternatywnych zrodel dochodu na obszarach wiejskich (Opportunities for developing alternative sources of income in rural areas). In: Pałka E. (ed.) Pozarolnicza działalność gospodarcza na obszarach wiejskich. Studia Obszarów Wiejskich, Warszawa, t. V, pp. 9-22.

2. Barrett, C. B., Reardon, T., Webb, P., (2001). Nonfarm Income Diversification and Household Livelihood Strategies in Rural Africa: Concepts, Dynamics, and Policy Implications. Food Policy, No 26, pp. 315-331.

3. Birthal, P.S., Negia, D.S., Jhab, A.K., Singhc, D. (2014). Income Sources of Farm Households in India: Determinants, Distributional Consequences and Policy Implications. Agricultural Economics Research Review, Volume 27, No 1, pp. 37-48.

4. Canagarajah, S., Newman, C., Bhattamishra, R. (2001). Non-farm Income, Gender, and Inequality: Evidence From Rural Ghana and Uganda. Food Policy, No 26 (4), pp. 405-420.

5. Charakterystyka gospodarstw w Polsce w 2016 r. (Characteristic of farms in Poland in 216). (2017). GUS, Warszawa.

6. Czapiewski, K. (2004). Wyposazenie infrastrukturalne i potencjal gospodarczy obszarow wiejskich a pozarolnicze funkcje gmin (Infrastructure and economic potential of rural areas and non-agricultural functions of municipalities). In: Palka E. (ed.) Pozarolnicza dzialalnosc gospodarcza na obszarach wiejskich. Studia Obszarow Wiejskich, Warszawa, t. V, s. 57-74.

7. Czudec A., Zajac, D. (2017). Non-farming Entrepreneurship in the Farm Activity Diversification Process. Journal Agribusiness Rural Development, No 43(1), pp. 69-78.

8. Kisiel, R., Jarzebowicz, N. (2017). Non-agricultural Business Activity in the Olecko District. Journal of Agribusiness and Rural Development, No 4(46), pp. 787-794.

9. Kolodziejczyk, D. (2004). Pozarolnicza dzialalnosc gospodarcza w indywidualnych gospodarstwach rolnych w skali gmin (Non-agricultural activity in individual farms in the scale of communes). In: Palka E. (ed.) Pozarolnicza dzialalnosc gospodarcza na obszarach wiejskich. Studia Obszarow Wiejskich, Warszawa, Volume V, pp. 23-34.

10. Krakowiak-Bal, A. (2009). Pozarolnicza działalnosc gospodarcza polskich gospodarstwach rolniczych na tle gospodarstw z krajow UE (Other gainful activity in agricultural holdings in Poland and EU countries). Infrastruktura i Ekologia Terenow Wiejskich. Polska Akademia Nauk, Oddzial w Krakowie, Komisja Technicznej Infrastruktury Wsi, No 5/2009, pp. 209-217.

11. Reardon T., Taylor J.E., Stamoulis K., Lanjouw P., Balisacan A. (2000). Effects of Nonfarm Employment on Rural Income Inequality in Developing Countries: an Investment Perspective. J. Agric. Econ., No 51 (2), pp. 266-288.

12. Von Braun, J., Pandya-Lorch, R. (1991). Income Sources of Malnourished People in Rural Areas: Microlevel Information and Policy Implications. International Food Policy Research Institute (IFPRI).

13. Weltin, M., Zasadaa, I., Frankeb, Ch., Piorra, A., Raggic, M., Viaggi, D. (2017). Analysing Behavioural Differences of Farm Households: An Example of Income Diversification Strategies Based on European Farm Survey Data. Land Use Policy, No 62 (2017), pp. 172-184.

14.Zmija, K. (2018). Determinanty i perspektywy prowadzenia dzialalnosci rolniczej w malych gospodarstwach rolnych z pozarolnicza dzialalnoscia gospodarcza (Determinants and Prospects of Conducting Agricultural Activities in Small Farms with Non-Agricultural Activities). Problemy Rolnictwa Swiatowego, Volume 18, Issue 2, pp. 342-352. 